Sághy Miklós

\title{
A privát szféra faggatása, avagy miról árulkodnak a családi filmek
}

\section{Szerzô}

Sághy Miklós a Szegedi Tudományegyetem Vizuális Kultúra és Irodalomelmélet Tanszékének docense. Tanulmányai, cikkei a kortárs magyar irodalom, film, az irodalom és a film kapcsolata, valamint a média- és metaforaelméletek témaköreiben jelentek meg.

E-mail cím: saghy.miklos@hung.u-szeged.hu

https://doi.org/10.31176/apertura.2018.13.1.5 


\section{Sághy Miklós}

\section{A privát szféra faggatása, avagy miról árulkodnak a családi filmek}

[Blos-Jáni Melinda: A családi filmezés genealógiája. Erdélyi amatốr médiagyakorlatok a fotózástól az új mozgóképfajtákig. Kolozsvár, Erdélyi Múzeum-Egyesület, 2015.]

\section{Tudományelméleti problémák a vizsgálandó anyaggal kapcsolatban}

Blos-Jáni Melinda 2015-ben megjelent, A családi filmezés genealógiáa címú könyve a filmkészítés egy nehezen hozzáférhetô területére, a családi mozgóképkészítési gyakorlatokra fókuszál. Mivel vizsgálatának anyaga javarészt privát archívumokban, személyes filmtárakban található, ezért egy olyan láthatatlan „alkotói” szférába kalauzolja olvasóját, ahol nem sokan jártak elootte. Vagy ha megfordultak is a szóban forgó területen - mint például Forgács Péter, a rendező, aki Privát Magyarország (1988-2002) címú projektjéhez gyújtött családi filmtárakból anyagokat -, áttekintô térképet nem készítettek, nem készíthettek róla, hisz ehhez elóbb a vizsgálandó archívumokat kellett volna felmérni, ám a családi filmkészítési praxisok esetében ez szinte lehetetlen vállalkozás, éppen az anyag rejtôzködô, privát természetébôl következően. A könyvben leírt kutatás tehát az imént vázoltak okán több tudománymódszertani kérdést is felvet. Mindenekelôtt azt, hogy miképpen lehetséges objektív, ellenôrizhetô (azaz intézményes) módon beszélni egy radikálisan szubjektív (informális) gyakorlatról, melynek teljes korpusza lényegében beláthatatlan. Vagyis: mit kezdjen a tudományos módszertan az intézményeken kívüli, mindennapi filmkészítési gyakorlatokkal? Egyáltalán miképpen határozható meg a családi filmezés jelensége például a „hivatalos” vagy független (ámde professzionális) filmes gyakorlatokhoz képest? Blos-Jáni Melinda könyve nem kerüli meg a szembesülést a vizsgálati tárgyát érintő alapvetô elméleti kérdésekkel; éppen ellenkezôleg: a szóban forgó munkában jelentôs teret kap a családi filmezésnek mint kutatási témának a meghatározása, valamint azoknak az adekvát módszereknek a kijelölése, melyekkel a szóban forgó téma - minden nehézség ellenére - ígéretesen vizsgálható.

A teoretikus okfejtést a vizsgálati terület definíciójával kezdi a szerzô, aki az amatôr filmek nagy halmazán belül elôször is kijelöli a családi filmek helyét. Az amatôr filmezés - írja - lényegében azt az alkotói praxist jelöli, mely kívül van a filmiparon, nem árucikkeket, kereskedelmi termékeket hoz létre, s ily módon eltér a hivatalos filmkészítés gyakorlatától. Ez egyfajta marginalizált pozíciót jelent az ipari filmtermeléshez képest, ugyanakkor az alkotói szabadság lehetôségét is magában hordozza. Az amatốr filmnek, mely tartalma és kontextusa szerint is tág gyújtőfogalomnak tekinthetô, alkategóriái a privát film és a családi film. Az utóbbi altípusba tartozó 
mozgóképek elsôsorban nem formanyelvi sajátosságaik, hanem a hozzájuk kapcsolódó társadalmi cselekvésformák alapján különülnek el a többi amatôr filmtől, hiszen a családi mozgóképeket társadalmilag jól definiálható közösségek készítik, nézik, jelesül a családok, és a hozzájuk kapcsolódó gyakorlatok (értelmezés, alkotás) döntôen a nevezett közösségek magánügyei. Ennyiben a családi filmezés praxisa privátnak tekinthetô. A privát film (angolul: home movie, home video) ugyanakkor a családinál tágabb fogalom, hiszen mindazt jelöli, ami a mozgókép társadalmi nyilvánosságán kívül esik, tehát „nemcsak a családban készült filmek tartoznak ide, hanem más logika szerint szervezôdô közösségi, egyéni igényeket kiszolgáló alkotások is” (15).

A privát film kérdéskörének hangsúlyos felértékelődése nyilván egybeesik a digitális médiumok elterjedésével, vagyis az újmédia korával, hiszen az új technológiák tették azt lehetôvé, hogy a házilag készített tartalmak a különbözô videomegosztók segítségével a nyilvános médiatér - akár nagyon is népszerú - részeivé válhassanak. Ebből következóen a széles tömegeknek megjelenési, (ön)reprezentálási felületet biztosító úgynevezett participatív médiakörnyezet döntôen átalakítja a privát és a publikus (informális/intézményes) tereket, s ily módon a privát filmes gyakorlatokat vizsgáló kutatót is elméleti reflexióra és mindezek számbavételére kényszeríti. $A$ családi filmezés genealógiája címú kötet érdeme, hogy nemcsak arra mutat rá, hogy a kortárs médiakörnyezet milyen kihívások elé állítja a privát (és ezen belül a családi) film vizsgálóját (valamint alkotóját), hanem arra a történelmi folyamatra is rávilágít (a szakirodalom segítségével, röviden), mely a privát filmek társadalmi térbe kerülésének mérföldköveiként értelmezhetôk. A privát film társadalmi-történeti jelentôségére, dokumentumértékére ugyanis mindenekelôtt az olyan események hívták fel a figyelmet, mint például az 1963-as Kennedy-gyilkosság, melynek nyomozati rekonstruálása során az amatốr filmes, Abraham Zapruder 8 mm-es magánfelvétele döntô jelentôséggel bírt. 1991-ben pedig „egy amatôr videofelvétel volt nagy hatással az amerikai társadalomra: George Holliday megörökítette, amint a Los Angeles-i rendôrség bántalmazza és letartóztatja az afroamerikai Rodney Kinget. A videofelvételt elóbb tévében közvetítették, majd a per sokat vitatott bizonyítékává vált” (15). A Holliday-felvételek, melyek többek közt utcai lázongásokat váltottak ki, élénk tudományos viták kereszttüzébe kerültek. A hozzászólók nagy része a szóban forgó anyagot a vizuális reprezentáció és a dokumentumfilmes kifejezés episztemológiai válságának emblematikus példájaként kezelte, mindenekelôtt azért, mert a vád és a védelem a mozgóképek homlokegyenest eltérô értelmezésével próbálta meg bizonyítani igazát a bíróságon. 
A privát film fontosságát növelte az a történelemtudományi paradigmaváltás is, mely a nagy narratívák felvázolása helyett az alternatív kis történetekre, a mindennapi élet kutatására helyezi a hangsúlyt. A mikrohistorikus megközelítés számára ugyanis a privát filmek (fotográfiák) olyan történeti dokumentumokat jelentenek, amelyek egyfelól a történelem alulnézetét nyújtják, másfelól pedig egy-egy korszak mentalitástörténetének nyomait hordozzák magukban. A családi filmek például a családmodellek koronkénti változásáról, a különbözô mozgóképrögzítô eszközökhöz fúződô emberi viszonyokról (vagyis az úgynevezett médiadomesztikáció folyamatáról) is árulkodhatnak - errôl a késôbbiekben még lesz szó.

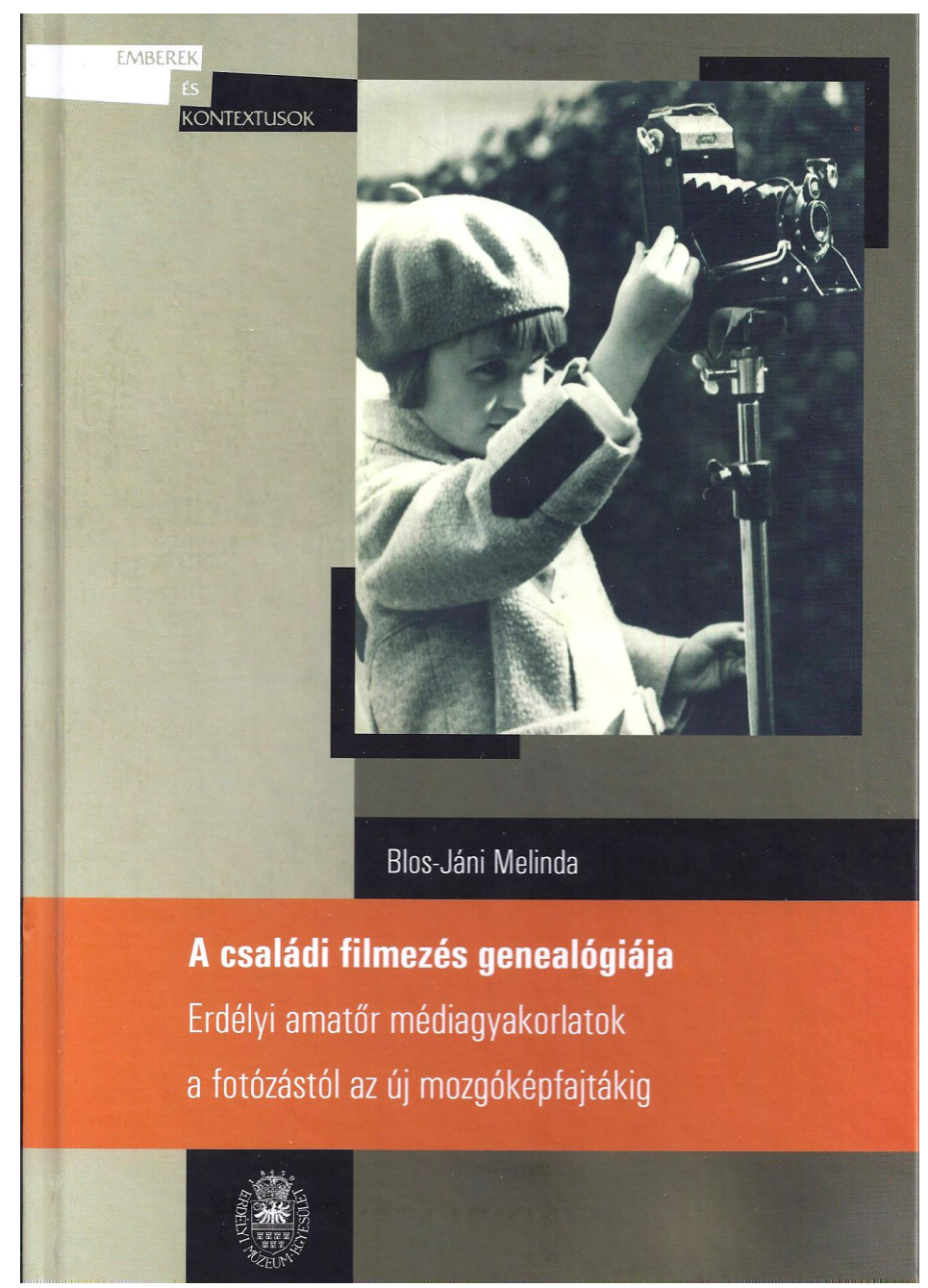

Blos-Jáni Melinda: A családi filmezés genealógiája. Erdélyi amatôr médiagyakorlatok a fotózástól az új mozgóképfajtákig

\section{A vizsgálati terület, a vizsgálati módszerek pontosítása}

A privát (s ezen belül a családi) filmek tárgyköréhez a kulturális antropológia módszereivel közelít a szóban forgó munka szerzője. Ennek megfelelóen a vizsgált dokumentumokat, archívumelemeket a vizuális kommunikáció olyan gyakorlataiként kezeli, melyeket megérteni, 
leírni elsôsorban a társadalmi, technológiai és kulturális meghatározottságok összjátéka felôl érdemes. Fontos ugyanakkor, hogy a privát filmezés praxisát alakító különbözố hatások történeti változásai is a kötet érdeklődésnek fókuszában állnak, vagyis a családi filmezést meghatározó kontextusok és egyéni döntések koronkénti eltérései, valamint idôbeli alakulásai.

A komplex, kontextusra is kiterjesztett vizsgálat a családi filmek (fotók) esetében azért is fontos, mert a szóban forgó vizuális produktumok jelentése nem határozható meg pusztán képi mivoltuk alapján. A családi képek, filmek ugyanis elválaszthatatlanok azoktól a társadalmi (közösségi) gyakorlatoktól, amelyekben tulajdonképpen felhasználásra kerülnek. Ez egyfelôl azt jelenti, hogy a családtagok, családi események azonosítása többlettudást, kiegészítô kontextuális ismereteket igényel, másfelôl meg azt, hogy a családi filmek privát képvilágát a felvétel, a rögzítés személyes módja, a befogadást pedig annak magánjellege határozza meg. A családi filmek szúk körú megtekintése során például a családtagok nagyon gyakran kommentekkel, történetekkel, anekdotákkal egészítik ki a látottakat, ami nem meglepő, hisz a privát mozgóképek legtöbbször az emlékfelidézés eszközeként funkcionálnak. Éppen ezért a családi film - a befogadás módját figyelembe véve - olyan „ösztönző jelnek” is tekinthetô, mely voltaképpen nézőjének a „belsô”, emlékidézô moziját stimulálja. Az emlékidézés gyakorlata során ugyanakkor a családtagoknak mintegy össze kell játszania, hogy a közös múltat rekonstruálni tudják, vagyis hogy végeredményben egy (mikro) emlékezetközösséget alkossanak. A családi filmekrôl leválaszthatatlanok tehát azok a tudásformák, narratívák, melyek „a kép témájával kapcsolatos élményeket jelentésteli keretekbe foglalják, de nem feltétlenül öltenek diszkurzív formát, és azok a szövegek, diskurzusok, melyek a képek nézésekor, mutogatásakor valamiként megfogalmazódnak, textualizálódnak" (38).

A családi filmezés genealógiája címú kötet történeti érdeklődése értelemszerúen kiterjed az imént vázolt, családi filmes gyakorlatok vizsgálatára (vagyis arra, hogy miképpen válik a családi emlékezet szervezôjévé különbözô korokban a kamera), valamint annak a folyamatnak a szemrevételezésére, hogy a mozgóképrögzítés technológiájának változása miképpen hatott a családi önreprezentáció praxisaira. Az utóbbi szempont vizsgálatának fontosságára éppen a kortársi médiakörnyezet alakulása hívja fel a figyelmet, hisz - a fent már említett - digitális médiatechnológiák forradalma többek közt a privát és a publikus tér jelenségeit, viszonyrendszerét alakította át radikálisan. S mivel mindezeket számításba veszi a szóban forgó kötet, nem csoda hát, hogy a mediális közvetítést - elsôsorban a családi és privát filmek tulajdonságaiból kiindulva - olyan jelenségként tételezi, amelyet „egyszerre konstruálnak a társadalmi gyakorlatok”, és „a médium technológiai aspektusainak változásai” (41).

A történeti vizsgálatok elsôdleges módszere a médiagenealógia, hiszen a családi filmek analízise során döntố jelentôségú szempont, hogy a különbözố rögzítési technikák mikor, mi módon jelennek meg és válnak a kultúra (s így a privát mozgóképkészítés) alakító tényezőjévé. A különböző genealógiai elképzelések - melyek egy-egy új kommunikációs technológia médiummá válásának, intézményesülésének folyamatát írják le - közös vonása, hogy az „új” médiumot a „régiek” viszonyrendszerében pozícionálják. David Bolter és Richard Grusin a remedializáció 
fogalmával jelölik azt a folyamatot, melynek során egy új médium a régiek formáját, technikai sajátosságait ölti magára, azzal a céllal, hogy az ismerôsség látszatát kihasználva minél szélesebb körben elfogadottá és népszerúvé válhasson. ${ }^{[1]}$ Blos-Jáni Melinda ugyanakkor nem a remedializáció, hanem az intermedialitás jelensége felól közelít a médiageneológia módszertanához. Eszerint, amikor egy új kommunikációs technológia megjelenik az emberi kultúrában, akkor a „legitimnek tartott médiagyakorlatok és múfajok kontextusába épül be. Ez egy spontán intermedialitás, ekkor a médium egyediségének kérdése még nem releváns, hiszen a korábbi médiumok társadalmi gyakorlatát egészíti ki, folytatja. Az intermediális kapcsolatok hatására következik be a felbukkanás mozzanata: az alakuló médium gyakorlata kezd elkülönböződni más médiumoktól, már nem viszonyul ezekhez mimetikusan. A második születés után a spontán intermediális viszonyok megszúnnek, helyette kialakul egy negociált intermedialitás, azaz a médiumok kapcsolata alárendelôdik (vagy legalábbis egyeztetve van) a kétszeresen megszületett médium identitásának" (44). A médiagenealógia intermediális megközelítése tehát abból indul ki, hogy egy új technológia útja különbözô mediális gyakorlatok átfedésein keresztül vezet az intézményesülés, az elfogadottság felé. A családi filmek esetében is jól megfigyelhetô (s a szóban forgó könyvben szemléletesen dokumentált) ez a folyamat. A házi mozgóképarchívumok ugyanis funkciójukat, formanyelvi megoldásaikat tekintve kezdetben a családi fényképalbumokkal mutatnak átfedést, rokonságot. A késôbb megjelenô képrögzítô technikák is (mint például a video, digitális felvevô) a már meglévô gyakorlatok kontextusába lépnek be, s alakítanak ki velük intermediális relációkat, miközben persze az „otthonos”, ismerôs médiumok identitásának újragondolására is kényszerítik (fel)használóikat.

Mivel a családi/privát film alapvetôen (használatát, létrejöttét tekintve biztosan) elkülönül az intézményesült mozgóképkészítési, -fogyasztási gyakorlatoktól, és döntôen az otthon teréhez kötôdik, ezért az ilyen típusú filmek (diakrón) vizsgálata lehetôséget ad annak a folyamatnak a leírására, melynek során egy új médiatechnika fokozatosan a (családi) mindennapok domesztikált részévé válik. A média hétköznapiasulásának, szakszerübben: a médiadomesztikáció folyamatának elemzése $A$ családi filmezés genealógiája címú kötetnek is fontos törekvése. A közel nyolcvan évet átfogó diakrón vizsgálat ugyanis nagy hangsúlyt fektet annak leírására és jellemzésére, hogy a különböző képrögzítési és -lejátszási technológiák hogyan épülnek be a háztartásokba: a családtagok milyen megfontolások alapján választanak ki egy-egy technológiát, miképpen hangolják az új „szerzeményhez” a szokásaikat, milyen új családi gyakorlatok jönnek létre ennek következtében, és nem utolsó sorban, miképpen épül (akár alakító módon is) az új technológia az emberi kapcsolatok hálózatába. 
A szóban forgó kötet tehát kifejtett céljainak megfelelôen egyfelől a családi filmezés technikatörténetét vizsgálja elsôsorban a médiageneológia módszertanára támaszkodva, másfelôl a jelenség társadalmi vonatkozásait veszi górcsố alá, döntôen a médiadomesztikáció folyamatára fókuszálva. Nyilván e két megközelítési szempont csupán elméleti szinten választható el egymástól (és erre reflektál maga a kötet is), hiszen a technikatörténet (melyet a médiagenealógia vizsgál) társadalmi hatását elemzi tulajdonképpen a család közegében a médiadomesztikáció kutatója.

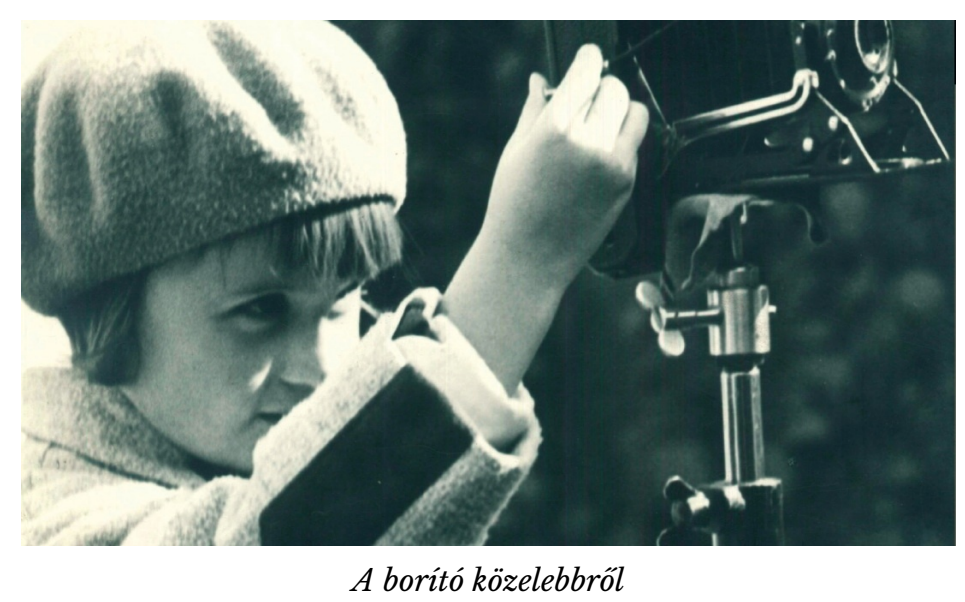

\section{Az archívumvizsgálatok}

A kötetben bemutatott elemzések 3 család 4 generációjának közel 80 éven átíveló filmkészítési szokásaira fókuszálnak. A fentebb vázolt módszertani kereteknek megfelelően a családi archívumok analízise elsősorban annak meghatározására irányul, hogy egy adott korszak filmezési technikái hogyan épültek a családok közösségi életterébe, és miképpen alakították, formálták azt.

A kolozsvári Orbán család filmgyưjteménye az amatôr filmezés úttörô példáját képviseli. A családi közösség privát mozgóképeit idősebb Orbán Lajos készítette egy kölcsönkamerával az 1920-as, 1930-as években. A marosvásárhelyi Haáz család három generációjának történetében már médiumváltást is megfigyelhetünk. Az elsô két generáció még analóg technikával, míg a harmadik már videotechnikával készíti családi filmjeit. A szintén marosvásárhelyi Keresztes családban pedig az analóg- és videotechnika mellett már a digitális képrögzítés és tárolás módjai is megjelennek. Vagyis a vizsgálati korpusz kronologikus jellege valóban a diakronikus vizsgálat lehetôségét ígéri.

A nevezett privát archívumokat kétségtelenül kimerítô alapossággal vizsgálja Blos-Jáni Melinda. Részletesen bemutatja a családok történetét, interjúkat készít a családtagokkal (ezekból részleteket is közöl), melyek során elsôsorban a filmezéshez fúzôdô viszonyukról, valamint az elkészült mozgóképek használatáról faggatja ôket. Precízen dokumentálja a megtekintett filmek tematikai, formai sajátosságait és számszerúsíthetô paramétereit. Az archívumok bemutatásának, leírásának ez a mélysége nyilván elvárható egy antropológiai irányultságú munkától. A vizsgált jelenség szakszerú felmérése, lokalizálása és mibenlétének meghatározása ugyanis elengedhetetlen a tudományos értékú következtetések megtételéhez. Mindazonáltal a nem szakmabeli olvasók tárgy 
iránti érdeklődését valószínúleg nem serkenti a számszerúsített adatolás, a részletezô katalogizálás. Kétségtelen persze, hogy az archívumok bemutatásának nehézsége azok privát jellegéból következik. Egyfelól ugyanis a családi gyứjtemények nem nyilvánosak, hozzáférhetôek, ezért egyegy utalással, hivatkozással nem tudja a szerzố az olvasóit (akár az állítások ellenôrzésének céljából is) a vizsgálati korpuszhoz irányítani; be kell tehát azokat részletesen mutatnia. Másfelól elemzésének tárgyai mozgóképek, s így azokat (vagy azok részleteit) demonstrációs céllal prezentálni nem tudja a szerzó a kötet keretei közt, más szóval: nem tudja kutatási „tárgyát” a szövegében közvetlenül idézni, csakis közvetve, a mozgóképek szóbeli bemutatásának segítségével. (S ezt a nehézséget csak részben orvosolják a filmekből kivágott állóképek, melyeket örömteli módon bóséggel találunk a szóban forgó munka végén, a Képmellékletek alcím alatt.)

Kifejezetten izgalmasak azok a részek, amelyek a társadalmi kontextusok vizsgálata során olyan amatốr filmes intézményeket mutatnak be, melyek a családi archívumok (archiválók) életében fontos szerepet játszottak. Ifjabb Orbán Lajos képrögzítéshez fúződô viszonyát például alapvetôen meghatározta egyfelól a Kovács P. Fiai fotóbolt, ahol először alkalmazottként, majd tulajdonosként tevékenykedett (és ahonnét felvételeihez a kamerát is hazavitte), másfelól azok az egyesületek (Tessar Teke Társaság, Erdélyi-Kárpát Egyesület), melyek az amatốr fotózással és filmezéssel foglalkozó embereket gyújtötték össze Kolozsváron az 1920-as, 1930-as években. Ifjabb Haáz Sándor és Keresztes Pál filmkészítôi habitusára pedig - állítja és bizonyítja is a szerzô Schnedarek Ervin filmkészítô legendás marosvásárhelyi múhelye és iskolája volt nagy hatással.

A korpusz átfogó, diakronikus vizsgálata több mintázatra is rámutat a családi archívumokkal kapcsolatban. Elôször is a kötet szemléletesen (vagyis példákkal igazoltan) vázolja, hogy a mozgóképrögzítés az évtizedek során miképpen vált az otthon természetes részévé. Ifjabb Orbán Lajos (1920-as, 1930-as években) még „kölcsönzött” kamerával dolgozott, idôsebb Haáz Sándor (az 1950-es, 1960-as években) a munkája révén (hisz táncfilmeket készít) vált amatôr filmessé, ám fiai Ferenc és Sándor, illetve Keresztes Pál (az 1970-es, 1980-as években) már az otthon „domesztikált” eszközeként használják a felvevôgépet. Pál fia, Péter pedig kezdetben a videotechnikát, majd a digitális eszközöket kezeli élete szerves részeként. Másodsorban a házi képrögzítés genealógiai történetét látja kitûnni vizsgálati anyagából a szerző. Eszerint a családi filmek készítése kezdetben (az 1920-as, 1930-as években) az amatôr fényképezési szokásokhoz igazodott, vagyis a fényképezés alárendeltje volt, majd a késôbbiekben fokozatosan elvált intermediális „rokonától”, s elôször a két médiumot (fotó, film) párhuzamosan használják a családi események rögzítésre, végül pedig önálló „identitással” ruházzák fel a mozgóképrögzítő kamerát a családi filmesek. Ezek a megfigyelések valóban fontos médiagenealógiai összefüggéseket tárnak fel, ám meggyôző erejüket némileg csökkenti, hogy a történeti folyamatok felvázolása mindösszesen három (meglehetôsen esetlegesen és véletlenszerúen fellelt) családi archívumon alapul. Nem könnyú persze privát archívumokat felkutatni és azokhoz hozzáférni, ám mégis: a nagyobb korpusz egyfelól jobban alátámaszthatta volna a történeti megfigyeléseket, másfelól akár újabb diakrón mintázatok megfigyelését is lehetôvé tehette volna.

Felettébb izgalmas része a szóban forgó munkának az a fejezet, mely a kamerába nézés történetét 
vizsgálja a családi filmekben. A kamera felé forduló emberi arc, melynek jelölésére a kameratekintet terminust használja a szerzô, jóllehet a családi filmekben gyakran megfigyelhetô, ám a számszerúsített statisztikák érdekes rajzolatot mutatnak diakronikus aspektusból. Eszerint ugyanis a kamerába nézés egyre ritkább lesz az évtizedek elôre haladtával, ami azt bizonyítja, hogy az új technológiák fokozatosan beépülnek a családi filmezés gyakorlatába, mondhatni domesztikálódnak, hiszen a családtagok láthatóan egyre fesztelenebbül és otthonosabban viselkednek a felvevôgép lencséje elôtt. Az Orbán család filmjein a kameratekintetek elemzése megmutatta, hogy „a gyerekek nem rendelkeztek saját reprezentációik fölött, hanem szülői, pontosabban apai irányításra játszottak el fotografikus pózokat a filmezés kedvéért. Ugyanakkor ez az apai tekintet a frontális pózokban és ünnepélyes arckifejezésekben lelte meg a hiteles, valószerú ábrázolás nyitját” (173). Ehhez képest a Haáz család 1970-es és 1980-as évekbeli Super 8-as filmjein a kamerába tekintés már nem jár együtt merev testtartással, statikussággal, sôt, éppen a spontaneitás és az esetlegesség válik fontossá, mégpedig azért, mert Haáz Ferenc történetesen a „hirtelen átváltozó, érzelmeket nyíltan kifejezó gyermekarcokat tanulmányozza kamerájával” (169). A Keresztes család filmjei pedig, melyek a videokorszakot, vagyis egy újabb médiatörténeti periódust képviselnek, azt példázzák, hogy a kamerának, felvevőgépnek már nincsen „rendet és egyenes testtartást parancsoló tekintélye, a gyerekek szabadon táncolhatnak, hancúrozhatnak és grimaszolhatnak a kamera elôtt" (174). Mindemellett a filmezés gyakorlatában is megfigyelhetô a demokratizálódás, hisz az apa gyakran átengedi gyerekeinek a kamerát, s ily módon ók is részt vehetnek a családi (mozgó)kép alakításában. Ez a fajta részvétel akár az újmédiumokhoz kapcsolódó participatív médiagyakorlatok irányába mutató tendenciaként is értelmezhetô, akárcsak a videót önreprezentációra használó Haáz gyerekek felvételei. A 2000-es évek családi filmjeinek narcisztikus gesztusai ugyanis már előre jelzik a majdani videomegosztó korszak fiatal generációjának az én-üzeneteket elôtérbe helyezô szelfikultúráját és vele együtt e reprezentációs mód széles körú elterjedését.

A kameratekintetetek történetének alapos vizsgálata arra is lehetôséget ad a szóban forgó kötet szerzőjének, hogy a kamerához fúződó emberi viszonyokon túl a kis közösségi kapcsolatok, a családi viszonyok alakulására vonatkozóan is következtetéseket vonjon le. A kamerát kezelô apa és a filmeken szereplố családtagok viszonya például láthatóan megváltozik az évtizedek során. Az 1930-as évekbeli mozgóképeken Orbán Lajos a családi színjátékok karakteres „rendezőjeként” azonosítható, míg az 1980-as évek Super 8-as filmjein az apák már nem vállalják a mindenható rendező szerepét: a gyerekek viselkedését nem igyekeznek a felvétel kedvéért rendszabályozni, és kerülik a beállított, teátrális képeket. A videokorszakot képviselô Keresztes Pál mozgóképkészítô praxisában már azt látjuk, hogy egyfelôl a gyerekeket is bevonja a filmkészítés folyamatába, másfelól pedig arra biztatja családtagjait, hogy a lehetô legspontánabb módon viselkedjenek a kamera elótt. Ehhez hasonlóan az apa-gyerekek viszonyról is árulkodnak a vizsgált archívumok, melyek általánosságban egy fokról-fokra informálisabb kapcsolat irányába mutató szülô-gyerek viszonyt rajzolnak ki.

Összességében, úgy vélem, többek között az imént vázolt összefüggések bemutatása és leírása 
miatt (is) oly izgalmas $A$ családi filmek genealógiája címú kötet. Ehhez egy olyan komplex módszertanra volt szüksége, mely egyként veszi górcsố alá a tágabb technológia- és társadalomtörténeti kontextust, valamint a családok privát történeteit, emlékezetnarratíváit. A családi filmezés problémakörét mintaértékú alapossággal és elméleti felkészültséggel vizsgálja a munka szerzôje, s ha bármi kétség felmerül az olvasóban, akkor az korántsem a módszerek adekvátságát, vagy az elemzések mélységét érinti, hanem - amiképpen errôl fentebb már szóltam - a vizsgált archívumok relatíve csekély számát. Egy-egy családi mozgóképtár alapján ugyanis (bármily reprezentatívak legyenek is azok önmagukban) különböző korszakokra vonatkozóan következtetéseket levonni kockázatos vállalkozás, még akkor is, ha a nagyobb vizsgálati korpusz feltehetôleg (de nem bizonyítottan) ugyanezeket a mintázatokat rajzolhatná ki. Illetve lehet olyan érzése a szóban forgó kötet olvasójának, hogy éppen ott ér véget a családi filmezés története, ahol kezdene felettébb izgalmassá válni: az újmédia, vagy ha tetszik, a participatív média megjelenésének idôszakánál; azon a ponton tehát, ahol radikális változások állnak be a családi filmezés gyakorlatában. Mindazonáltal ez nem kritika akar lenni, inkább csak egy olvasói vágy megfogalmazása, ugyanis a szóban forgó kötet példaértékú pontossággal jelöli ki vizsgálati korpuszát, és ebbe már nem tartozik bele az újmédia korszaka. Csak remélni lehet, hogy a szóban forgó munka folytatásaként a családi filmezést radikálisan átalakító kortársi folyamatoktól is ír majd egy könyvet - hasonló alapossággal és körültekintéssel - Blos-Jáni Melinda. ${ }^{[2]}$

\section{Jegyzetek}

1. Bolter, David - Grusin, Richard: Remediation: Understanding New Media. Cambridge, MIT Press, 2000.

2. Jelen írás létrejöttét az EFOP-3.6.2-16-2017-00007 azonosító számú, Az intelligens, fenntartható és inkluzív társadalom fejlesztésének aspektusai: társadalmi, technológiai, innovációs hálózatok a foglalkoztatásban és a digitális gazdaságban címú projekt támogatta. A projekt az Európai Unió támogatásával, az Európai Szociális Alap és Magyarország költségvetése társfinanszírozásában valósul meg.

\section{Irodalomjegyzék}

- Blos-Jáni Melinda: A családi filmezés genealógiája. Erdélyi amatốr médiagyakorlatok a fotózástól az új mozgóképfajtákig. Kolozsvár, Erdélyi Múzeum-Egyesület, 2015.

- Bolter, David - Grusin, Richard: Remediation: Understanding New Media. Cambridge, MIT Press, 2000.

\section{Filmográfia}

- Privát Magyarország (Forgács Péter, 1988-2002) 
(C) Apertúra, 2017. Ỗsz | www.apertura.hu

webcím: https://www.apertura.hu/2017/osz/saghy-a-privat-szfera-faggatasa-avagy-mirol-

arulkodnak-a-csaladi-filmek/

https://doi.org/10.31176/apertura.2018.13.1.5

(Q)opertúro 